\title{
The Development of Critical Thinking for Students in Vietnamese Schools: From Policies to Practices
}

\author{
Ho Thi Nhat ${ }^{1, *}$, Nguyen Thi Lien ${ }^{2}$, Nguyen Thi Tinh ${ }^{1}$, Ngo Vu Thu Hang ${ }^{3}$, Nguyen Thu Trang ${ }^{2}$ \\ ${ }^{1}$ Faculty of Psychology and Education, Hanoi National University of Education, Hanoi, Vietnam \\ ${ }^{2}$ Institute for Educational Research, Hanoi National University of Education' Hanoi, Vietnam \\ ${ }^{3}$ Faculty of Primary Education, Hanoi National University of Education, Hanoi, Vietnam \\ *Corresponding author: nhatht@hnue.edu.vn
}

Received March 11, 2018; Revised April 14, 2018; Accepted April 17, 2018

\begin{abstract}
Developing critical thinking for students has recently gained significant attention in global educational discourse and practices, in response to social demands for autonomous citizens in a knowledge-based economy. In Vietnam, the objective of developing critical thinking for students has now become one of the central focuses in the new general educational program required by the government. However, a critical review of literatures on critical thinking, the new general educational program, and practices of teaching and learning in Vietnamese schools, reveals a number of potential hindrances for the changes, including a lack of clear and detailed guidance in the new program regarding critical thinking, teachers' beliefs and teaching habits, a passive and examination-oriented learning culture, and traditions of hierarchy and face saving. To make teaching for critical thinking reality, there needs to be cooperation and participation from all parties from policy makers to teacher-training universities, local educational departments, schools, families, teachers and students in establishing a clear schedule for the implementation of a social constructivist approach in teaching and learning.
\end{abstract}

Keywords: critical thinking, development of critical thinking for students, Vietnamese schools, policies and practices

Cite This Article: Ho Thi Nhat, Nguyen Thi Lien, Nguyen Thi Tinh, Ngo Vu Thu Hang, and Nguyen Thu Trang, "The Development of Critical Thinking for Students in Vietnamese Schools: From Policies to Practices." American Journal of Educational Research, vol. 6, no. 5 (2018): 431-435. doi: 10.12691/education-6-5-10.

\section{Introduction}

Critical thinking is generally conceptualized as cognitive skills at higher thinking level in which individuals demonstrate the abilities to evaluate the values of ideas, arguments, and situations. Along with creative and problem-solving thinking, critical thinking is considered crucial in a knowledge-based economy [1], since it can help students to become autonomous citizens. Schools around the world therefore are enjoined to teach students how to think critically.

In the wave of reforming its educational system, Vietnam has recently paid significant attention in the development of higher order thinking skills for students. The new general education program, which has been officially promulgated in 2017 and will start taking effect from the academic year of 2019-2020, requires schools to move from a content-based curriculum to a competencebased curriculum approach [2]. The new program clearly states one central focus of schools is to develop critical thinking, creative and problem-solving competence for students. This new program, however, is claimed by many Vietnamese researchers as ambitious due to a range of inhibitive sociocultural factors and established teaching and learning traditions.

Vietnam is a country in the Southeast Asia, where peoples' thinking and behaviors are significantly influenced by a collective spirit and 'face saving' culture. That is, maintaining a harmonious atmosphere in a community and making a good impression on others is deemed crucial in the minds of Vietnamese. People therefore may avoid critical thinking as this could be misunderstood as personal criticism, creating conflicts and breakdown in relationships. As a result, the tradition of respect for harmony and 'face saving' may inhibit students' habits of questioning the ideas of others [3]. Further, as Vietnam is a Confucian-influenced culture, hierarchical traditions between teachers and students have existed in classrooms; this may impede a culture of questioning and interacting, considered to be conductive environments for critical thinking. Consequently, these cultural values should be taken into account when implementing teaching for critical thinking at schools in Vietnam.

This paper will describe changes in the new general education programs regarding critical thinking and analyze potential sociocultural barriers for the changes and suggest possible solutions to reduce the gaps between policies and practices. 


\section{Content}

\subsection{Critical Thinking Skills in Students}

\section{What is critical thinking?}

Definitions of critical thinking are various. Historically, Socrates - an ancient Greek philosopher - was deemed to be the first to mention this approach to learning through the technique often called 'Socratic questioning'. The technique highlights the importance of raising appropriate questions for any information that we have received. However, John Dewey - an American philosopher and Psychologist - is often referred to as the father of critical thinking, as he was the first person who coined the term 'reflective thinking' $[4,5]$. Dewey claims that 'reflective thinking' is the core element in becoming an autonomous learner, as this is an active process showing a persistent and careful consideration of a belief based on supported evidence which later lay the foundation for further conclusions and implications [5]. According to Dewey, the main features of reflective thinking include the abilities of an individual to be the owner of their thinking, to raise questions and to find relevant information, as well as reasoning to support or reject a particular belief.

Understandings about critical thinking have evolved over the years and a critical reviewing of the literature reveals two typical ways of defining the term. One popular understanding that has gained agreement from the majority of educators and researchers is built on the concept of Dewey's reflective thinking [5]. Thus, critical thinking is understood as the individual ability to inquiry, verify, and evaluate any phenomenon in a thoughtful way before making any decision [6]. Others define critical thinking as the process of "thinking about thinking" [7]. The focus of this approach is to unpack what actually underpins critical thinking. For example, Paul (1993) considers critical thinking is a mode of thinking focusing on development of metacognition. Consequently, fundamental critical thinking skills may include skills for identification of the elements, evaluation of assumptions and arguments, classification and interpretations of expressions and ideas, analysis and synthesis, drawing arguments, inferences, and conclusions.

Many researchers consider that providing a succinct definition of critical thinking is difficult as it is complex concept $[4,5,8]$. In a nutshell, critical thinking is a kind of higher order thinking skill in which individuals demonstrate their abilities to scientifically and thoughtfully evaluate a phenomenon from different perspectives and in different contexts in order to make a final effective decision. These abilities require people to possess a range of skills such as questioning, inquiry, evaluation, and decision making.

What are the characteristics of a critical thinker?

As critical thinking is an active and purposeful thinking process that requires one to consider and evaluate carefully any phenomenon before making any decision, it requires thinking skills. Showing mastery in skills of investigation, analysis, synthesis, comparison, generalization and evaluation is crucial to critical thinkers, as they use metacognition skills to evaluate, make decisions, and successfully solve problems. Further, having a sufficient base knowledge is also vital. It is argued that it is hard to think critically about something if one knows nothing about it [9]. As a result, it is essential that a critical thinker has wide and deep disciplinary and interdisciplinary knowledge. Critical thinking is also contrasted with an unbalanced view in which weaknesses are more highlighted. Instead, individuals should have abilities to see both the strengths and weaknesses in any given claims [10]. In other words, an open, fair, and constructive mind is the relevant attitude for critical thinking. Additionally, to gain insightful understandings on the phenomenon, individuals should possess a skeptical attitude [11] and the ability to raise appropriate questions for any situation and claim.

There has been concern about the possibility that critical thinking could impede creative thinking [10]. It was reasoned that critical thinking often requires one to closely follow rules in providing arguments and evaluation, while creative thinking may be based on breaking rules to create new things. However, most researchers now believe that critical thinking is one crucial element of creative thinking and problem solving $[10,12,13]$. To create new things or solutions for problems, it is important to evaluate carefully what has existed already. Further, when making conclusions and final decision on solutions, critical thinking definitely plays a role. It is suggested that critical thinking can be learnt and teaching critical thinking is not separate from teaching creative and problem solving thinking, as they are generally interwoven $[10,12]$.

\subsection{Teaching for Critical Thinking Development in Schools}

Research has shown that students who think critically possess a skeptical, an open/fair attitude, a wide range of knowledge, divergent thinking, and the abilities to question, find relevant evidence and reasons for any assumptions [11]. They should be able to provide their own persuasive arguments, suggest alternative solutions to problems, and evaluate and make final decisions on problems. Therefore, development of critical thinking for students should focus on teaching them both content/knowledge and methods of finding, processing, and evaluating information.

Many ways are suggested to develop critical thinking for students; three major ways have emerged from the practices, including teaching critical thinking directly, indirectly and a combination of both. Direct teaching means critical thinking is taught in a separate subject, while indirect teaching involves the development of critical thinking for students through existing subjects. The third approach combines the two ways. According to Bailin et al. (1999), the combination of direct and indirect teaching approaches for critical thinking development was found to be more successful in teaching critical thinking [14]. It should be noted that many effective practices reflect the use of a social constructivist approach in designing curriculum, teaching, and assessment.

The social constructivist approach considers learning as the consequence of social interactions of members in a particular community; learning is a mediated and situated process. The mediating nature of learning is reflected through the theory of zone of proximal development (ZPD) of Vygotsky. Vygotsky defines ZPD as "the distance between the actual development level as determined by independent problem solving and the level of potential development as determined through problem solving under adults' guidance or in collaboration with 
more capable peers" [[15], p. 86]. The theory of ZPD may suggest that the best learning occur in cooperative and interactive classrooms in which students are central in their learning. They are encouraged to proactively investigate and evaluate phenomenon. The situated nature of learning suggests that learning is influenced by the sociocultural settings in which it is happening $[16,17]$.

A social constructivist approach to learning is appropriate to the development of critical thinking. It is widely accepted that the focus of a transmission teaching model is on imparting knowledge; students are usually passive in their learning. A social constructivist approach encourages students to be agents in their own learning. They need to self- organize, self-regulate, and self-reflect via cooperation and interactions with others. The principles of a social constructivist approach would trigger discussions and debates among students which not only help them gain deep understanding of a phenomenon, but also encourage individual students to voice their own opinions and have opportunities for practicing 'reflective thinking'.

Using the principle of a social constructivist approach to learning, heuristic teaching methods [18] that are more likely to develop critical thinking for students are suggested: project-based learning, inquiry-based learning, problembased learning, and questioning. These teaching strategies would create a conductive environment for students to practice skills of investigating, scrutinizing, and evaluating a phenomenon which are essential for students to be critical thinkers [19].

\subsection{Policies on the Development of Critical Thinking for Vietnamese Students}

From 2006 until now, Vietnam has been using a content-based curriculum approach in which the main focus is on transmitting factual knowledge to students rather than giving students the opportunity to gain indepth understanding, solve problems and make their own decisions. As a result, developing critical thinking appears not to be the main focus in the current curriculum and therefore few teachers have paid attention to the development of this kind of thinking skill for their students. Consequently, critical thinking skills in Vietnamese students appeared weak [20].

The Vietnamese government has recognized the limitations of a content-based curriculum approach and decided to move to a competence-based curriculum approach. A new general educational curriculum was first drafted in 2015 and officially promulgated in 2017. Nevertheless, apart from core eight specialized competences, including competences in languages, numeracy, social and nature discovery, technology, computing, esthetic and physical, schools in Vietnam will have to focus on forming three major general competences: autonomous and independent learning, communication and cooperation, and creative and problem-solving [2].

Fostering critical thinking for students is stated in the new general educational program as part of the creative and problem solving competence and under the name 'independent thinking' [2]. According to the new program, this kind of thinking is shown through students' abilities to question, listen and accept information with thoughtful consideration and relevant evidence, evaluating a phenomenon from various perspectives and suggest solutions for problems.

It appears that despite using a different name, the skills that the Vietnamese government expects schools to develop for students in the new program is clearly critical thinking. To foster critical thinking, the new program requires schools to shift from a traditional transmission teaching model towards an interactive teaching approach. Teachers play the role of facilitators while students are agents in their own learning. They are encouraged to actively contribute to classroom activities such as inquiry, solving problems, discussions through working independently and collaboratively [2,21]. Although positive changes in policies are evident, it is still a long path to make the innovative objective a reality, due to several challenges from Vietnamese existing sociocultural values and teaching and learning traditions.

\subsection{Hindrances for Critical Thinking Development in Vietnamese Schools and Suggestions to Move Forward}

\section{Lack of clear description and implementation in policies}

As mentioned in the previous section, though the objective of fostering critical thinking is set in the new general educational program, it appears to be subsumed into the creative and problem solving competence. To make the objective reality in teaching practices, it is recommended that critical thinking must be emphasized as the 'target competence' [22]. This is because if critical thinking is considered a sub-set of creativity and solving problem competence, it is not considered as important to teachers. Further, Trần Thị Bích Liễu et al. (2016) found that the lack of clear guidance for teachers in terms of teaching for creative thinking competence has contributed to restricted practices [23]. Critical thinking is a new and ambitious objective that needs further documents to guide teachers in how to help students to be critical thinkers in specific subjects.

\section{Teachers' beliefs and teaching habits}

Since 1986, the Vietnam educational system has undergone several reforms, and training courses have been provided for teachers in order to equip them with innovative teaching approaches and techniques. However, research has found that the traditional teaching and learning styles still dominate in Vietnamese schools $[16,24,25]$. That is, teachers play the central role in the classroom and do almost activities, while students are passive, simply receiving factual information imparted from teachers. Additionally, the over-dependency on textbooks in teaching and learning was evident and this was found to be one barrier for fostering critical thinking in Vietnamese schools. Research conducted by Ngô Vũ Thu Hằng et $\mathrm{al}$. (2015) revealed that the textbook was used as the main teaching and learning source for both teachers and students in science classrooms at primary level [26]. Teachers tended to use only textbooks to transmit factual information. They interacted with students in class by asking questions; students simply found information in the textbooks to give answers. While critical thinking requires students to access a variety of sources in order to gain deep understanding of a 
phenomenon from various perspectives, an overdependence on the textbook by teachers and students could hinder critical thinking development. This suggests that teaching and learning resources should be upgraded and there needs to be a radical shift in the approaches to teaching and learning in Vietnamese schools.

Teachers' beliefs about learning and teaching play a crucial role in the development of critical thinking. Research conducted by Masa (2014) found that some teachers who consider teaching as a process of knowledge transmission limit the possibility for critical thinking development, whereas those who believe that learning is co-constructed through interaction between teacher and students organize more critical thinking activities in their classrooms [8].

Research reveals further that some Vietnamese teachers possess a biased belief that as critical thinking is considered one of high order thinking skills; it is suitable for teaching only excellent students [27]. If their classrooms have more students with average achievement in learning, then teaching for critical thinking maybe not their focus. Much research has indicated that critical thinking is teachable [18], and there is empirical evidence for development of critical thinking in students in various achievement categories. Research conducted by Lê Trung Tín and Nguyễn Hữu Châu on Grade 10 students in five provinces in North Vietnam found that students with various learning results made progress in their critical thinking skills after receiving lessons designed in ways that encourage them to raise questions and evaluate and predict information. These authors suggested that teachers should change their established beliefs, because critical thinking could be learned by every student. What teachers should do is to recognize the characteristics of critical thinking in different student groups to design well lessons which cater for every student [27].

More importantly, for new practices, teachers need support in terms of training and supervision. Research has also found that if teachers receive training in teaching critical thinking, they then perform teaching for critical thinking $[19,28]$. This may suggest that successful implementation of critical thinking development may require professional development specifically focusing on critical thinking and how to help students become critical thinkers.

Innovative approaches for pre-service teachers' critical thinking development in teacher-training universities were found to have a positive impact on teachers' practices for critical thinking. Trumbull and Slack (1999) believe that teachers who experienced traditional educational environments would fail to develop constructivist ideas about teaching and learning [28]. This suggests that teacher-training universities must encourage pre-service teachers to think critically through using a social constructivist approach. In other words, to foster practices of teaching for critical thinking in schools, pedagogical universities in Vietnam must reform their own teaching practices in ways that critical thinking is significantly addressed.

Water-rice and Confucian-influenced cultural values

Research has found many sociocultural hindrances to the development of critical thinking for students in Vietnam. These may include a passive learning culture for the sake of examination, face saving, and hierarchical relationships between teachers and students

\section{Passive and examination-oriented learning culture}

As the teacher-centered approach to teaching has persisted, Vietnamese students are used to learning passively. They often listen and take notes on what the teacher said and consider teachers' ideas the most accurate source of information. This could limit chances for students to develop their own thinking, and inhibit the development of critical thinking skills [3, 25]. Moreover, as teaching and learning in Vietnamese schools are mainly directed by examinations and testing, the focus of teaching and learning is on helping students to pass the exams with high results rather than to apply knowledge in practice. To tackle these challenges, there needs to be radical changes in the teaching and learning culture. A social constructivist approach that makes a revolutionary shift in the roles of the teacher and students should be considered; however, this requires appropriate time and adaptation to be successful in the Vietnamese context [29, 30].

\section{Hierarchical relationships and face saving}

Due to the influence of hierarchy in Confucius culture, teachers in Vietnam are considered the most reliable source of knowledge [22]. This may inhibit scientific argument within the classroom between teacher and students. Scientific discussion and argumentation can help students think critically and creatively in order to understand phenomena in depth, the tradition of hierarchy would make Vietnamese students hesitant to question the teacher [31,32]. Further, the face saving culture could make students unwilling to voice their own ideas or to give direct arguments or comments to their peers, as they may be afraid of causing conflict $[29,32]$. Ngô Vũ Thu Hằng et al. (2017) showed that the implementation of argumentation is a challenge for both teachers and students in terms of developing critical thinking [33]. Therefore, it is suggested that critical thinking skills such as scientific argumentation should be fostered, practiced and integrated in the curriculum $[18,33]$.

\section{References Formats}

Development of critical thinking for students is one of the central objectives that schools today need to help students become autonomous citizens in the $21^{\text {st }}$ century. The Vietnamese government has put significant emphasis on the development of critical thinking for students in the new educational program. However, there are sociocultural factors that may impede the implementation of the new program regarding critical thinking. These include a lack of clear and detailed guidance in the new program, teachers' beliefs and teaching habits, a passive and examinationoriented learning culture, and traditions of hierarchy and face saving.

To overcome those challenges, there needs to be cooperation and participation from all parties from policy makers to teacher-training universities, local educational departments, schools, families, teachers and students in establishing a clear schedule for the implementation of teaching for critical thinking. Importantly, development of critical thinking must become independent competence rather than being the sub-set of the creative and problem solving competence and it should be integrated into study of all other subjects, as basic as writing in any subject. It 
is suggested that along with teacher preparation, changes through continuing professional development, innovations and practices for critical thinking must be presented in teacher-training universities where pre-service teachers have the opportunity to experience and practice their critical thinking and learn how to teach their students to be critical thinkers in future.

\section{Acknowledgements}

This paper was completed with support and funding from Institute for Educational Research, Hanoi National University of Education, Vietnam.

\section{References}

[1] Bailin, S., (2002). Critical thinking and science education. Science \& Education, Vol. 11, Issue 4, pp 362-375.

[2] MOET. (2017). Chương trình giáo dục phổ thông tổng thể - [The new general educational programs in Vietnam]. Hanoi.

[3] Nguyen, K. D., \& Mcinnis, C. (2002). The possibility of using student evaluations in Vietnamese higher education. Quality in Higher Education, 8(2), 151-158.

[4] Dinuta, N. (2015). The use of critical thinking in teaching geometric concepts in primary school, Social and Behavioural Sciences, 180, 788-794.

[5] Fisher, A. (2001). Critical thinking: an introduction. What is critical thinking and how to improve it? Cambridge: Cambridge University Press.

[6] Ennis, R. H. (1989). Critical thinking and subject specificity: Clarification and needed research. Educational Researcher, 18(3), 4-10.

[7] Halpern, D. F. (1998). Teaching critical thinking for transfer across domains: Dispositions, skills, structure training, and metacognitive monitoring. American Psychologist, 53(4), 449-455.

[8] Masa, S. (2014). The development of critical thinking in primary school: The role of teacher's beliefs. Social and Behavioural Sciences, 141, 387-392.

[9] Garside, C. (1996). Look who's talking: A comparison of lecture and group discussion teaching strategies in developing critical thinking skills. Communication Education, 45, 212-227. Retrieved from EBSCO Online Database SocINDEX with Full Text.

[10] Nguyễn Gia Cầu. (2013). Bồi dưỡng, phát triển tư duy phản biện cho học sinh trong quá trình dạy học [Nurturing and developing critical thinking for students in teaching]. Educational Research Review, 311, 27-29.

[11] Trần Thúc Trình. (2005). Tư duy phê phán [Critical thinking] Journal of Educational Science Information, 114, 41-43.

[12] Phan Thị Luyến. (2007). Mối quan hệ giữa việc rèn luyện tư duy phê phán và tư duy sáng tạo cho học sinh trung học phổ thông trong dạy học Toán [Relationship between the development of critical thinking and creative thinking for students in teaching Mathematics]. Journal of Educational Sciences, 26, 25-28.

[13] Đỗ Thị Thu Thủy. (2016). Tư duy phê phán - nhìn từ góc độ giáo dục [Critical thinking - understanding from the educational perspective]. Education and Society, February, 32-34.

[14] Bailin, S., Case, R., Coombs, J.R., \& Daniels, L.B. (1999), Conceptualizing critical thinking, Journal of Curriculum Studies, 31(3), 285-302.

[15] Vygotsky, L. S. (1978), Mind in Society: The development of higher psychological processes. Cambridge: Harvard University Press.
[16] Rogoff, B. (2008). Thinking with the tools and institutions of culture. In P. Murphy \& K. Hall (Eds.), Learning and practice: Agency and identities (pp. 49-70). London: The Open University.

[17] Wenger, E. (2008). Identity in practice. In K. Hall, P. Murphy \& J. Soler (Eds.), Pedagogy and practice: Culture and identities (pp. 105-114). London: The Open University.

[18] Snyder, L.G. \& Snyder, M.J. 2008. Teaching Critical Thinking and Problem Solving Skills. The Delta Pi Epsilon Journal, 1 (2). 90-99.

[19] Florea, N. M., \& Hurjui, E. (2015). Critical thinking in elementary school children. Social and Behavioural Sciences, 180, 565-575.

[20] Lâm Thị Thanh Tuyền., \& Trần Thị Nam. (2016). Phát triển năng lực tư duy phản biện cho học sinh thông qua dạy học đọc hiểu văn bản môn Ngữ văn [Developing critical thinking for students through teaching reading comprehension skills in language arts]. Education and Society, September, 33-36.

[21] MOET. (2013). Nghị quyết số 29-NQ/TW [Resolution No29 on the radical and comprehensive reform of Vietnamese educational system]. Hanoi.

[22] Ngô Vũ Thu Hằng, \& Nguyễn Thị Liên (2017). Critical thinking: why it is needed to develop for Vietnamese students and what are the challenges? HNUE Journal of Science, Educational Sciences, 62(12).

[23] Trần Thị Bích Liễu., Hồ Thị Nhật., \& Hurle, R. J. (2016). Teaching for creativity development: Lessons learned from a preliminary study of Vietnamese and International Upper (high) secondary school teachers' perceptions and lesson plans Creative Education.

[24] Đặng Tự Ân, (2015). Model of Vietnam new school - A theoretical and practical view. Vietnam Education Publishing House.

[25] Harman, K., \& Nguyen, T. N. B. (2010). Reforming teaching and learning in Vietnam's higher education system. In G. Harman (Ed.), Reforming higher education in Vietnam (pp. 65-86): Springer.

[26] Ngô Vũ Thu Hằng, Meijer, M.R., Bulte, A., Pilot, A., 2015. The implementation of a social constructivist approach in primary science education in Confucian heritage culture: the case of Vietnam. Cultural Studies of Science Education, 10(3), 2015, 665-693.

[27] Lê Trung Tín \& Nguyễn Hữu Châu (2015). Đặc điểm của tư duy phê phán của các nhóm đối tượng học sinh trung học phổ thông trong học Toán [Characterisitcs of critical thinking in different student groups in learning Mathematics]. Journal of Educational Sciences, 117, 9-11.

[28] Trumbull, D.J., Slack, M.J. (1999). Learning to ask, listen and analyse: Using structured interviewing assignments to develop reflection in pre-service science teachers. International Journal of Science Education 13(2), 129-142.

[29] Nhat, H. T., Adie, L., \& Klenowski, V. (2016). The prospects for Assessment for Learning in higher education in Asian Settings: The case of Vietnam. Assessment Matters.

[30] Phạm Thi Hồng Thanh (2011). Effect of assessment on cooperation among Vietnamese college students. Higher Education Review, 43(2), 42-55.

[31] Hofstede, G., \& Bond, M. H. (2005). The Confucius connection: From cultural roots to economic growth. from http://www.sciencedirect.com/science/article/pii/00902616889000 95.

[32] Pham Thi Hong Thanh. (2014). Cooperative learning in CHC countries. In T. H. T. Pham (Ed.), Implementing cross-culture pedagogies (pp. 29-50). Singapore: Springer Verlag.

[33] Ngô Vũ Thu Hằng, Bulte, A., Pilot, A., (2017). Interaction of Vietnamese teachers with a social constructivism-based primary science curriculum in a framework appropriate for a Confucian heritage culture. Asia-Pacific Science Education, 3(2). 